\title{
Understanding consumer satisfaction with railway transportation service: An application of 7Ps marketing mix
}

\author{
Quang Hung Doa and Thi Hai Anh Vu ${ }^{b^{*}}$
}

${ }^{a}$ Faculty of Information Technology, University of Transport Technology, Hanoi, Vietnam

${ }^{b}$ Faculty of Transport Economics, University of Transport Technology, Hanoi, Vietnam

\section{H R O N I C L E}

\section{Article history:}

Received: September 25, 2019

Received in revised format: November 192019

Accepted: November 20, 2019

Available online:

November 20, 2019

Keywords:

Railway transport

Services Marketing

7Ps marketing mix

Customer satisfaction

\begin{abstract}
A B S T R A C T
Railway transportation (RT) plays a crucial role and it is an inseparable part of one country's main traffic network. However, due to the advantages of aviation industry and other modes of transportation, the share of RT of total traffic volume gradually decreases and RT enterprises are facing various difficulties. Customer satisfaction is one of the essential factors for the survival of any business organization. In order to accordingly offer products and services, RT companies must understand their customers and find out to what extent the consumer is satisfied with their offered services and products. The objective of this study is to evaluate the effect of each factor on the passengers' satisfaction and freight owners for RT service in Vietnam's context. The study utilizes 7Ps marketing mix (Product, Price, Place, Promotion, People, Process and Physical evidence) to analyze the customer satisfaction level. The collected data are analyzed through the multiple regression method by the use of SPSS software to understand the relationship of marketing mix elements and consumers' satisfaction. The study finding helps us guide the RT operators on their marketing strategy formulation. Customers will benefit through enhanced knowledge regarding both core and augmented products associated with RT services. It is also expected that this work can be used as a reference material for RT managers to enhance competitiveness.
\end{abstract}

C) 2020 by the authors; licensee Growing Science, Canada

\section{Introduction}

Transportation is an integral part in the existence and social-economic development of each local, zone, country, region and the world. Transportation plays an important role in helping distribute and circulate goods and products quickly and timely; it meets the travelling demand of human beings. Railway transport (RT), since its origin till the present, has always played a crucial role and is an inseparable part of the whole country's main traffic network. Currently, RT enterprises are facing challenges and difficulties due to the increase in advantageous conditions in competition with other modes of transportations. One of the measures to overcome the difficulties and challenges of the transportation market is that rail transportation enterprises must find the necessary measures to attract more customers to their business. Customer satisfaction is a vital factor to be successful in the marketplace and is considered as a key performance indicator (Mostaghel, 2006). Customer satisfaction is a business term to measure how products and services meet or surpass customer expectation. Marketing is all activities undertaken by a company to create relationships with and satisfy customers. Marketing theory has been widely applied in the business services sector, including the transport sector. The science of marketing research will help RT companies understand the customers and the transportation market, which is one of the conditions for railway transport enterprises to exist and develop in the transport market.

\footnotetext{
* Corresponding author.

E-mail address: anhvth@utt.edu.vn (T.H.A. Vu) 
Research on marketing and RT sector is not new. Vargo and Lusch (2004) conducted a comprehensive assessment and analysis of the origins of service marketing, practices and marketing strategies. They concluded that firms should focus more than just creating goods and the exchange of information (part of relationships). Laisi (2010) evaluated the Russian railway freight market's main national peculiarities and examined the barriers to entry and realize the market's problems and positive factors. The study indicated that the main national peculiarities in Russian railway freight market is associated with personal relations. Beck (2011) conducted an empirical analysis on 11 rail companies. The research findings determined whether market entry barriers exist in this market. Based on the marketing theory, it can be concluded that the customer satisfaction and its maintenance is directly related to the return on investment, sales profits, growth in market share, and lowering costs. The effective components of services marketing on the customer satisfaction include product, place, process, people, promotion, physical evidence, and price. The variables of the current study are the same factors influencing on services marketing, the use of which can be effective on maximizing the consumption, customer satisfaction, right to choose, and services quality. Therefore, this study aims to investigate whether each of 7P marketing mix components can affect the RT customers' satisfaction in Vietnam.

In the current study, authors attempt to look at customer satisfaction and identify the most influential factors in enhancing the customer satisfaction with RT service in Vietnam's context and provide its recommendations to improve weak points by studying marketing mix including price, place, promotion, product, personnel, procedure management and physical assets.

\section{7Ps marketing mix components}

The marketing mix is a series of marketing tools that an organization uses to produce the response it wants from its various target markets. It includes any measure that the organization can do to influence the demand for the services that it offers. A 4Ps (Product, Price, Place and Promotion) model is commonly used in manufacturing industry in which products are tangible; meanwhile, the service industry uses a 7Ps approach to satisfy the customers' needs: product, price, place, promotion, people, physical facilities and processes (Ivy, 2008). The products of service industry have specific characteristics including intangibility, heterogeneity, inseparability and perishability (Agu et al., 2017; Jin \& Suh, 2005). The 4Ps includes four elements (traditional marketing mix elements) namely product, price, promotion and place. Because any change on each element should be compatible with other elements, marketing mix term was chosen (Mullins et al., 2012). The product is what is being sold. Companies must determine what customers need and then develop the exact product with the suitable quality to meet their expectations. Pricing is a prominent element in the model of services marketing (Wood \& Pierson, 2006). The dimensions of pricing include list price, discounts, allowances, payment term and credit terms. It can be concluded that pricing has a significant effect on customer motivation. Promotion is identified as sales promotion, advertising, personal selling and public relations.

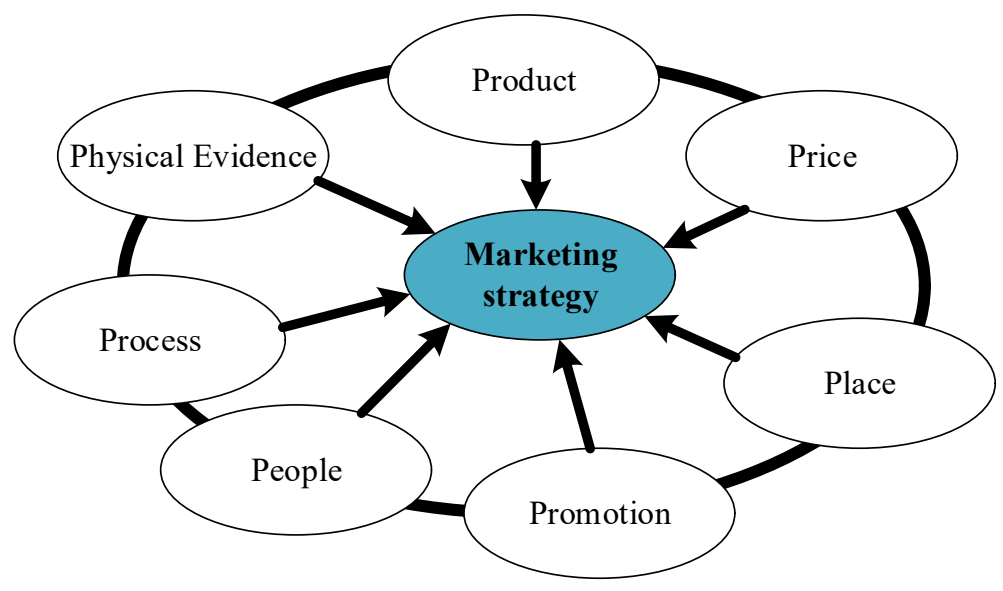

Fig. 1. Elements in 7Ps model

Promotion activities are conducted to create awareness about a brand and to communicate with present and potential stakeholders, and the general public (Duncan, 2005). Place (or distribution) is defined as a set of interdependent organizations involved in the process of making a product available for consumption by consumers. The product should be available in the right place, at the right time and in the right quantity, while keeping storage, inventory and distribution costs to a reasonable level. It was found that there are positive relationships between distribution intensity or efficiency and brand preference, loyalty and patronage (Kim \& Hyun, 2011; Tolba, 2011). It was believed that services need a different type of marketing mix (Booms \& Bitner, 1982). Therefore, three Ps namely personnel, physical assets and procedures were included and finally 7Ps were shaped (Rafiq \& Ahmed, 1995). Regarding people in 7Ps, the quality, skills and attitude of staffs/employees to a certain extent shape customers' decisions (Agu \& Ogbuji, 2008). The RT enterprises have such employees/staffs as train driver, customer service officers, operations managers, operations staff, waybill officers, security personnel, porters/lodgers, as well as offline staff, accounts officers, auditors. Service process means the process of delivering the product/service, and the behavior of those who deliver it, are important to customer satisfaction. Product/service attractiveness to consumers can be 
improved by providing timely, quick and accurate or error free services (Agu \& Ogbuji, 2008). Physical evidence comprises of the factors which are integrated into a service to make it tangible and measurable. Due to similarities in services' characteristics, 7Ps model can be applied to RT services.

\section{Methodology}

\subsection{The proposed model}

The model development includes the following steps:

- Assumptions of the model:

P1: The more diversity of RT services, the easier the customers to choose the service and the higher the customer satisfaction is.

P2: The more competitive the fares and freight rates are, the more satisfied the customers are.

P3: The availability of ticket types, the easiness of contract signing and the convenience in payment increase the customer satisfaction.

P4: The easier the access to discount programs, promotions, advertisements, the more satisfied the customers are.

P5: The better the service staffs are, the more satisfied the customers are.

P6: The more standardized the service process is, the more satisfied the customers are.

P7: The better the physical evidence is, the more the satisfaction level is.

- Measurement scale: Using a qualitative scale in an ascending order from 0 to 10 , of which 0 is customers "strongly dissatisfied" and 10 is customers "strongly satisfied" with the service provided.

- Data analysis includes Cronbach's coefficient alpha test; the multiple regression method; ANOVA analysis.

- Applicability of the model: 7Ps service marketing model to analyze the customer satisfaction is applied based on the survey results of customers' opinions who use RT services. The satisfaction of customers is assessed through questionnaires or survey results.

\subsection{Data collection}

Two surveys were conducted to collect information and opinions from passenger and merchandise owner from May 2018 to June 2019. The passengers' questionnaire consists of three parts: the first part includes demographic information such as age, gender, the frequency of using RT service; the second part includes the satisfaction of using RT services. The second part has 27 question items. The questions were asked on a 10-point Likert scale from 0 (strongly dissatisfied) to 10 (strongly satisfied). The third part offers open-ended questions that ask passengers to add their personal comments and suggestions. Similarly, the merchandise owners' questionnaire consists of three parts and the second part includes 26 question items. The paper questionnaires were delivered by hand (manually) to every respondent. The survey took no more than 30 minutes to complete. In the passenger survey, 200 questionnaires were delivered. After excluding incomplete and invalid responses, 196 questionnaires were used for analyzing the data. In the merchandise owner survey, of 150 questionnaires we delivered, 145 questionnaires were valid.

\subsection{The satisfaction model for passengers}

In order to determine the satisfaction level of passengers (PS) based on the 7 variables of RT service marketing, the research proposes a model of analyzing the relationship of 7 factors to the overall satisfaction level of the passengers, characterized by the coefficients $\beta_{P i}(\mathrm{i}=0-7)$. Details of the questions are given in Table 1 as follows,

Table 1

Items on the passengers' satisfaction level

\begin{tabular}{|c|c|c|}
\hline \multirow{2}{*}{$\begin{array}{l}\text { Code } \\
\text { Products }\end{array}$} & \multicolumn{2}{|r|}{ Passengers' satisfaction level on RT service } \\
\hline & & \\
\hline \multirow{4}{*}{ PP1 } & PP11 & Providing product information to passengers \\
\hline & PP12 & The ease level in choosing the route \\
\hline & PP13 & Punctuality \\
\hline & PP14 & The ease level in switching to other modes of transport \\
\hline \multicolumn{3}{|l|}{ Ticket price } \\
\hline \multirow{4}{*}{ PP2 } & PP21 & The reasonability of ticket price \\
\hline & PP22 & The information of ticket price \\
\hline & PP23 & The diversity of ticket price in each service \\
\hline & PP24 & The promotional ticket price \\
\hline
\end{tabular}


Table 1

Items on the passengers' satisfaction level (Continued)

Place (distribution system)

\begin{tabular}{|c|c|c|}
\hline \multirow{4}{*}{ PP3 } & PP31 & At station \\
\hline & PP32 & Online \\
\hline & PP33 & The availability of various ticket types \\
\hline & PP34 & The payment method \\
\hline \multicolumn{3}{|l|}{ Promotion } \\
\hline \multirow{4}{*}{ PP4 } & PP41 & The dispersion of promotional campaigns \\
\hline & PP42 & The company's perceived image \\
\hline & PP43 & The dispersion of advertising campaigns \\
\hline & PP44 & Other promotional activities \\
\hline \multicolumn{3}{|l|}{ People } \\
\hline \multirow{4}{*}{ PP5 } & PP51 & The staff dress appropriately and politely. \\
\hline & PP52 & The staff is polite and service-minded. \\
\hline & PP53 & The staff has good foreign skills. \\
\hline & PP54 & The staff provides accurate information. \\
\hline \multicolumn{3}{|l|}{ Service process } \\
\hline \multirow{3}{*}{ PP6 } & PP61 & The service process of departing passengers \\
\hline & PP62 & The process of serving the arriving passengers \\
\hline & PP63 & The process of serving in railway wagons \\
\hline \multicolumn{3}{|c|}{ Physical evidence (transport and station facilities) } \\
\hline \multirow{4}{*}{ PP7 } & PP71 & The comfort of transport and station facilities \\
\hline & PP72 & The cleanness of stations and railway wagons \\
\hline & PP73 & Audio equipment \\
\hline & PP74 & The guide posts at station \\
\hline
\end{tabular}

\section{Table 2}

Results of the Cronbach's alpha test for the passengers

\begin{tabular}{|c|c|c|c|c|c|c|c|}
\hline No. & Variable & Number of items & Cronbach alpha & No. & Variable & Number of items & Cronbach alpha \\
\hline 1 & Product (PP1) & 4 & 0.739 & 5 & People (PP5) & 4 & 0.718 \\
\hline 2 & Price (PP2) & 4 & 0.613 & 6 & Process (PP6) & 3 & 0.722 \\
\hline 3 & Place (PP3) & 4 & 0.612 & 7 & Physical assess (PP7) & 4 & 0.637 \\
\hline 4 & Promotion (PP4) & 4 & 0.615 & & & & \\
\hline
\end{tabular}

Table 3

Results of Cronbach's alpha test for items

\begin{tabular}{|c|c|c|c|c|c|}
\hline No. & Code & $\begin{array}{c}\text { Scale mean if item } \\
\text { deleted }\end{array}$ & $\begin{array}{c}\text { Scale variance if } \\
\text { item deleted }\end{array}$ & $\begin{array}{c}\text { Corrected item-total } \\
\text { correlation }\end{array}$ & $\begin{array}{c}\text { Cronbach's Alpha if } \\
\text { item deleted }\end{array}$ \\
\hline \multicolumn{6}{|c|}{ Results of Cronbach's alpha test of PP1 } \\
\hline 1 & PP11 & 17.13 & 3.346 & 0.616 & 0.633 \\
\hline 2 & PP12 & 17.13 & 4.649 & 0.448 & 0.724 \\
\hline 3 & PP13 & 17.13 & 4.902 & 0.506 & 0.703 \\
\hline 4 & PP14 & 17.62 & 3.846 & 0.599 & 0.639 \\
\hline \multicolumn{6}{|c|}{ Results of Cronbach's alpha test of PP2 } \\
\hline 5 & PP21 & 19.78 & 5.711 & 0.352 & 0.571 \\
\hline 6 & PP22 & 20.27 & 5.601 & 0.440 & 0.518 \\
\hline 7 & PP23 & 19.77 & 4.157 & 0.504 & 0.447 \\
\hline 8 & PP24 & 20.14 & 5.538 & 0.302 & 0.610 \\
\hline \multicolumn{6}{|c|}{ Results of Cronbach's alpha test of PP3 } \\
\hline 9 & PP31 & 20.27 & 4.350 & 0.370 & 0.564 \\
\hline 10 & PP32 & 19.95 & 4.161 & 0.470 & 0.477 \\
\hline 11 & PP33 & 19.66 & 5.342 & 0.415 & 0.542 \\
\hline 12 & PP34 & 20.28 & 4.829 & 0.344 & 0.577 \\
\hline \multicolumn{6}{|c|}{ Results of Cronbach's alpha test of PP4 } \\
\hline 13 & PP41 & 19.69 & 4.687 & 0.440 & 0.511 \\
\hline 14 & PP42 & 20.51 & 4.836 & 0.382 & 0.554 \\
\hline 15 & PP43 & 20.66 & 4.286 & 0.423 & 0.525 \\
\hline 16 & PP44 & 20.37 & 5.302 & 0.340 & 0.583 \\
\hline \multicolumn{6}{|c|}{ Results of Cronbach's alpha test of PP5 } \\
\hline 17 & PP51 & 18.06 & 4.925 & 0.471 & 0.687 \\
\hline 18 & PP52 & 19.26 & 5.114 & 0.593 & 0.605 \\
\hline 19 & PP53 & 18.47 & 5.184 & 0.426 & 0.714 \\
\hline 20 & PP54 & 19.71 & 5.992 & 0.628 & 0.626 \\
\hline \multicolumn{6}{|c|}{ Results of Cronbach's alpha test of PP6 } \\
\hline 21 & PP61 & 11.74 & 1.845 & 0.637 & 0.523 \\
\hline 22 & PP62 & 12.34 & 2.809 & 0.549 & 0.637 \\
\hline 23 & PP63 & 12.25 & 2.876 & 0.483 & 0.702 \\
\hline \multicolumn{6}{|c|}{ Results of Cronbach's Alpha of PP7 } \\
\hline 24 & PP71 & 19.33 & 5.895 & 0.434 & 0.558 \\
\hline 25 & PP72 & 19.22 & 5.549 & 0.412 & 0.573 \\
\hline 26 & PP73 & 18.73 & 5.027 & 0.426 & 0.569 \\
\hline 27 & PP74 & 18.70 & 6.415 & 0.421 & 0.574 \\
\hline
\end{tabular}


Table 2 indicates that all Cronbach's alpha coefficient $>0.6$, which shows the questionnaire is reliable (Nunnally \& Bernstein, 1994). The corrected item - total correlation shows how much each item correlates with the overall questionnaire score. Correlations less than .30 indicate that the item may not belong on the scale. In Table 3 all corrected item - total correlation $>.30$ indicates that the corresponding item correlate very well with the overall scale.

Table 4

Passengers' satisfaction statistics

\begin{tabular}{|c|c|c|c|c|c|c|}
\hline No. & Code & No. of samples & Min & Max & Mean & Std. dev \\
\hline 1 & PP11 & 196 & 5 & 8 & 5.87 & 1.057 \\
\hline 2 & PP12 & 196 & 5 & 8 & 5.87 & 0.803 \\
\hline 3 & PP13 & 196 & 5 & 7 & 5.88 & 0.668 \\
\hline 4 & PP14 & 196 & 5 & 8 & 5.38 & 0.918 \\
\hline 5 & PP21 & 196 & 5 & 8 & 6.87 & 0.966 \\
\hline 6 & PP22 & 196 & 5 & 8 & 6.39 & 0.896 \\
\hline 7 & PP23 & 196 & 5 & 8 & 6.88 & 1.245 \\
\hline 8 & PP24 & 196 & 5 & 8 & 6.51 & 1.088 \\
\hline 9 & PP31 & 196 & 5 & 8 & 6.45 & 1.125 \\
\hline 10 & PP32 & 196 & 5 & 8 & 6.77 & 1.069 \\
\hline 11 & PP33 & 196 & 5 & 8 & 7.06 & 0.752 \\
\hline 12 & PP34 & 196 & 5 & 8 & 6.44 & 1.003 \\
\hline 13 & PP41 & 196 & 5 & 8 & 7.39 & 0.983 \\
\hline 14 & PP42 & 196 & 5 & 8 & 6.57 & 1.003 \\
\hline 15 & PP43 & 196 & 5 & 8 & 6.41 & 1.127 \\
\hline 16 & PP44 & 196 & 5 & 8 & 6.70 & 0.903 \\
\hline 17 & PP51 & 196 & 5 & 8 & 7.11 & 1.143 \\
\hline 18 & PP52 & 196 & 5 & 8 & 5.91 & 0.962 \\
\hline 19 & PP53 & 196 & 5 & 8 & 6.69 & 1.122 \\
\hline 20 & PP54 & 196 & 5 & 8 & 5.45 & 0.696 \\
\hline 21 & PP61 & 196 & 5 & 8 & 6.42 & 1.100 \\
\hline 22 & PP62 & 196 & 5 & 8 & 5.83 & 0.811 \\
\hline 23 & PP63 & 196 & 5 & 8 & 5.91 & 0.840 \\
\hline 24 & PP71 & 196 & 5 & 8 & 6.00 & 1.018 \\
\hline 25 & PP72 & 196 & 5 & 8 & 6.11 & 1.143 \\
\hline 26 & PP73 & 196 & 5 & 8 & 6.60 & 1.271 \\
\hline 27 & PP74 & 196 & 5 & 8 & 6.63 & 0.882 \\
\hline 28 & PS & 196 & 5 & 7 & 6.11 & 0.461 \\
\hline
\end{tabular}

In order to investigate the passengers' satisfaction (PS) on RT services, the multiply regression analysis was adopted. In the analysis, PP1, PP2, PP3, PP4, PP5, PP6 and PP7 are independent variables; the passengers' satisfaction (PS) is dependent variable. The multiply regression equation can be written as:

$$
P S=\beta_{P 0}+\beta_{P 1} P P 1+\beta_{P 2} P P 2+\beta_{P 3} P P 3+\beta_{P 4} P P 4+\beta_{P 5} P P 5+\beta_{P 6} P P 6+\beta_{P 7} P P 7,
$$

where, $\beta_{P i}(\mathrm{i}=1 \ldots 7)$ are beta coefficients - one to go with each independent variable. In the equation, since the constant (beta zero) is included, these coefficients are unstandardized. In this study, the data were analyzed using SPSS version 20.0. The results of analysis are presented in Table 5.

\section{Table 5}

Multiple regression results of the analysis on passengers' satisfaction

\begin{tabular}{|c|c|c|c|c|c|}
\hline \multirow{2}{*}{ Variable } & \multicolumn{2}{|c|}{ Unstandardized Coefficients } & \multirow{2}{*}{$\begin{array}{c}\text { Standardized Coefficients } \\
\text { Beta } \\
\end{array}$} & \multirow[b]{2}{*}{$\mathrm{t}$} & \multirow[b]{2}{*}{ Sig. } \\
\hline & $\beta_{\mathrm{i}}$ & Std. Error & & & \\
\hline (Constant) & $\beta_{P 0}=-0.355$ & 0.458 & & -0.774 & 0.440 \\
\hline PP1 & $\beta_{P 1}=0.157$ & 0.038 & 0.222 & 4.157 & 0.000 \\
\hline PP2 & $\beta_{P 2}=0.185$ & 0.034 & 0.288 & 5.483 & 0.000 \\
\hline PP3 & $\beta_{P 3}=0.188$ & 0.035 & 0.275 & 5.285 & 0.000 \\
\hline PP4 & $\beta_{P 4}=0.080$ & 0.037 & 0.119 & 2.163 & 0.032 \\
\hline PP5 & $\beta_{P 5}=0.171$ & 0.033 & 0.272 & 5.245 & 0.000 \\
\hline PP6 & $\beta_{P 6}=0.091$ & 0.035 & 0.146 & 2.607 & 0.010 \\
\hline PP7 & $\beta_{P 7}=0.143$ & 0.032 & 0.234 & 4.424 & 0.000 \\
\hline
\end{tabular}

Table 6

Results of ANOVA test for the passengers' satisfaction model

\begin{tabular}{lccccc}
\hline Model & Sum of Squares & df & Mean Square & F & Sig. \\
\hline Regression & 21.685 & 7 & 3.098 & 29.348 & $0.000^{\mathrm{b}}$ \\
Residual & 19.845 & 188 & 0.106 & \\
\hline Total & 41.531 & 195 & $\mathrm{R}^{2}$ test & \\
\hline \multicolumn{7}{c}{ Adjusted $\mathrm{R}^{2}$} & Std. Error of the Estimate \\
\hline Model & $\mathrm{R}$ & $\mathrm{R}^{2}$ & 0.504 & 0.325 \\
\hline 1 & $0.723^{\mathrm{a}}$ & 0.522 & &
\end{tabular}


With Sig $<5 \%$, all regression coefficients $\beta_{P i}(\mathrm{i}=0-7)$ are statistically significant. $\mathrm{F}$ value of 29.348 and $\mathrm{Sig} .=0.000<5 \%$ (ANOVA test); $\mathrm{R}^{2}=0.522$ ( $\mathrm{R}^{2}$ test) show that the model is a good fit for the data and $52.2 \%$ of the variance was accounted for. The regression equation would be:

$$
P S=-0.355+0.157 . P P 1+0.185 . P P 2+0.188 . P P 3+0.08 . P P 4+0.171 . P P 5+0.091 . P P 6+0.143 . P P 7
$$

It can be concluded that Place (PP3) and Price (PP2) are the most influential factor in creating passengers' satisfaction.

\subsection{The satisfaction model for freight owners}

In order to determine the satisfaction level of freight owners (OS) based on the 7 variables of RT service marketing, the research proposes a model of analyzing the relationship of 7 factors to the overall satisfaction level of the freight owners, characterized by the coefficients $\beta_{O i}$ ( $\left.\mathrm{i}=0-7\right)$.

\section{Table 6}

Items on the freight owners' satisfaction level

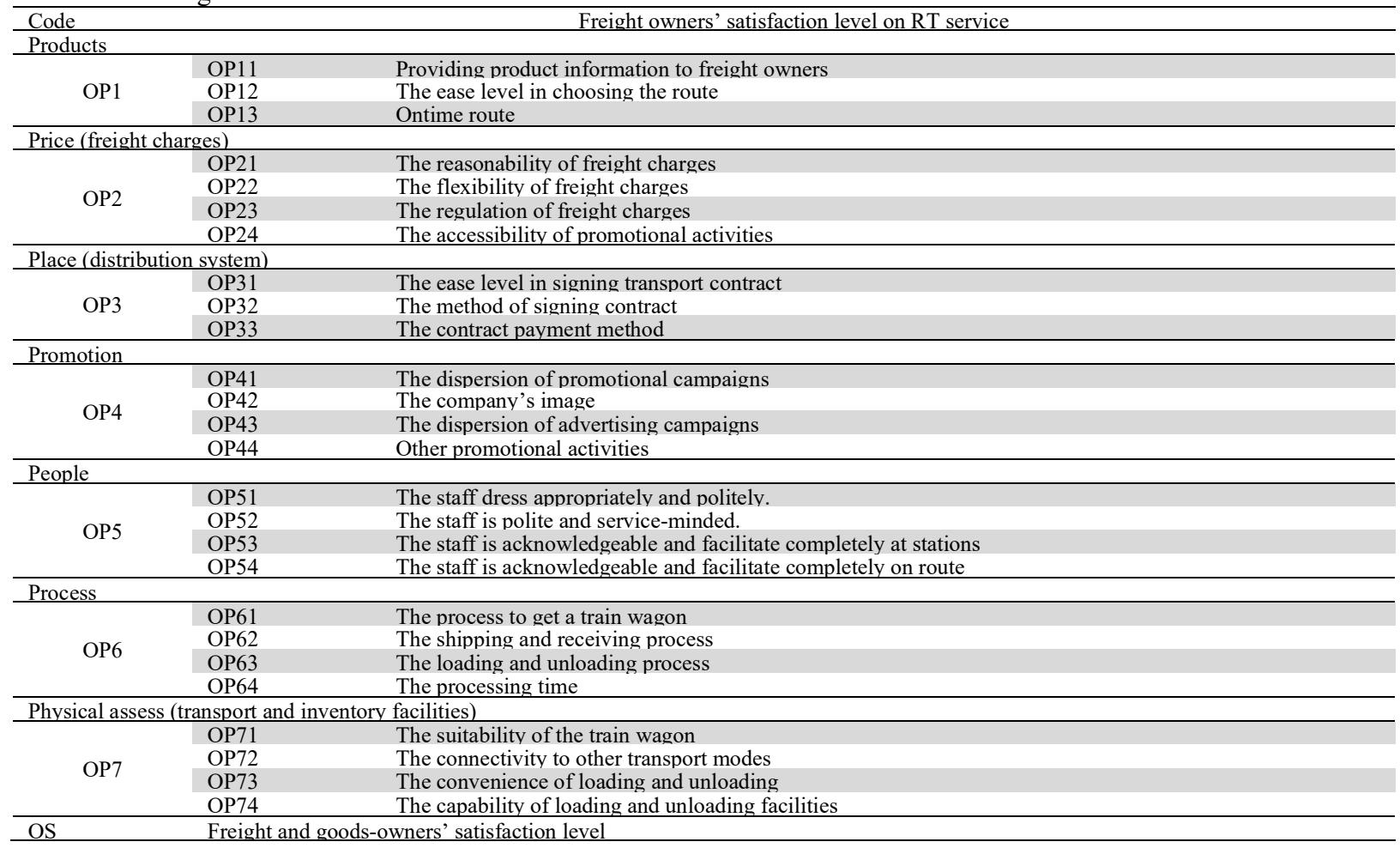

In order to investigate the effect of 7Ps elements on the freight owners' satisfaction level, 7 predictors (independent variables) including OP1, OP2, OP3, OP4, OP5, OP6 and OP7 were split into 26 observed variables. Table 7 indicates that all Cronbach's alpha coefficient $>0.6$, which shows the questionnaire is reliable. The corrected item - total correlation shows how much each item correlates with the overall questionnaire score. Correlations less than .30 indicate that the item may not belong on the scale. In Table 8, all corrected item - total correlation $>.30$ indicates that the corresponding item correlate very well with the overall scale.

Table 7

Results of the Cronbach's alpha test for the freight owner

\begin{tabular}{clcc}
\hline No. & Variable & Number of items & Cronbach alpha \\
\hline 1 & Product (OP1) & 3 & 0.617 \\
2 & Price (OP2) & 4 & 0.613 \\
3 & Place (OP3) & 3 & 0.649 \\
4 & Promotion (OP4) & 4 & 0.718 \\
5 & People (OP5) & 4 & 0.803 \\
6 & Process (OP6) & 4 & 0.639 \\
7 & Physical assess (OP7) & 4 & 0.648 \\
\hline
\end{tabular}


Table 8

Results of Cronbach's alpha test for all predictors

\begin{tabular}{|c|c|c|c|c|c|}
\hline No. & Code & $\begin{array}{c}\text { Scale mean if item } \\
\text { deleted }\end{array}$ & $\begin{array}{c}\text { Scale variance if item } \\
\text { deleted }\end{array}$ & $\begin{array}{c}\text { Corrected item-total } \\
\text { correlation }\end{array}$ & $\begin{array}{c}\text { Cronbach's Alpha if } \\
\text { item deleted }\end{array}$ \\
\hline \multicolumn{6}{|c|}{ Results of Cronbach's alpha test of OP1 } \\
\hline 1 & OP11 & 11.34 & 1.989 & 0.466 & 0.484 \\
\hline 2 & OP12 & 12.13 & 2.976 & 0.491 & 0.465 \\
\hline 3 & OP13 & 11.92 & 2.918 & 0.368 & 0.596 \\
\hline \multicolumn{6}{|c|}{ Results of Cronbach's alpha test of OP2 } \\
\hline 4 & OP21 & 19.97 & 5.270 & 0.332 & 0.585 \\
\hline 5 & OP22 & 20.46 & 4.611 & 0.455 & 0.501 \\
\hline 6 & OP23 & 19.83 & 4.375 & 0.399 & 0.539 \\
\hline 7 & OP24 & 20.27 & 4,115 & 0.402 & 0.540 \\
\hline \multicolumn{6}{|c|}{ Results of Cronbach's alpha test of OP3 } \\
\hline 8 & OP31 & 13.56 & 3.848 & 0.493 & 0.505 \\
\hline 9 & OP32 & 13.31 & 3.815 & 0.483 & 0.522 \\
\hline 10 & OP33 & 12.77 & 5.128 & 0.420 & 0.610 \\
\hline \multicolumn{6}{|c|}{ Results of Cronbach's alpha test of OP4 } \\
\hline 11 & OP41 & 19.47 & 7.478 & 0.533 & 0.640 \\
\hline 12 & OP42 & 20.40 & 7.484 & 0.502 & 0.658 \\
\hline 13 & OP43 & 20.60 & 7.069 & 0.496 & 0.664 \\
\hline 14 & OP44 & 20.32 & 7.599 & 0.494 & 0.663 \\
\hline \multicolumn{6}{|c|}{ Results of Cronbach's alpha test of OP5 } \\
\hline 15 & OP51 & 17.95 & 7.011 & 0.597 & 0.769 \\
\hline 16 & OP52 & 19.21 & 7.323 & 0.676 & 0.726 \\
\hline 17 & OP53 & 18.44 & 7.103 & 0.556 & 0.792 \\
\hline 18 & OP54 & 19.67 & 8.388 & 0.722 & 0.734 \\
\hline \multicolumn{6}{|c|}{ Results of Cronbach's alpha test of OP6 } \\
\hline 19 & OP61 & 19.00 & 7.738 & 0.391 & 0.589 \\
\hline 20 & OP62 & 19.02 & 7.882 & 0.333 & 0.629 \\
\hline 21 & OP63 & 18.24 & 6.611 & 0.428 & 0.568 \\
\hline 22 & OP64 & 18.29 & 7.475 & 0.558 & 0.490 \\
\hline \multicolumn{6}{|c|}{ Results of Cronbach's alpha test of OP7 } \\
\hline 23 & OP71 & 16.95 & 4.529 & 0.568 & 0.467 \\
\hline 24 & OP72 & 17.08 & 6.443 & 0.368 & 0.619 \\
\hline 25 & OP73 & 17.14 & 6.690 & 0.394 & 0.609 \\
\hline 26 & OP74 & 17.34 & 5.190 & 0.419 & 0.594 \\
\hline
\end{tabular}

Table 9

Freight owners' satisfaction statistics

\begin{tabular}{|c|c|c|c|c|c|c|}
\hline No. & Code & No. of samples & Min & Max & Mean & Std. dev \\
\hline 1 & OP11 & 145 & 5 & 8 & 6.36 & 1.188 \\
\hline 2 & OP12 & 145 & 5 & 8 & 5.57 & 0.798 \\
\hline 3 & OP13 & 145 & 5 & 8 & 5.77 & 0.934 \\
\hline 4 & OP21 & 145 & 5 & 8 & 6.88 & 0.832 \\
\hline 5 & OP22 & 145 & 5 & 8 & 6.39 & 0.914 \\
\hline 6 & OP23 & 145 & 5 & 8 & 7.01 & 1.051 \\
\hline 7 & OP24 & 145 & 5 & 8 & 6.57 & 1.129 \\
\hline 8 & OP31 & 145 & 5 & 8 & 6.30 & 1.221 \\
\hline 9 & OP32 & 145 & 5 & 8 & 6.56 & 1.235 \\
\hline 10 & OP33 & 145 & 5 & 8 & 7.10 & 0.852 \\
\hline 11 & OP41 & 145 & 5 & 8 & 7.52 & 0.944 \\
\hline 12 & OP42 & 145 & 5 & 8 & 6.57 & 1.032 \\
\hline 13 & OP43 & 145 & 5 & 8 & 6.37 & 1.160 \\
\hline 14 & OP44 & 145 & 5 & 8 & 6.66 & 1.010 \\
\hline 15 & OP51 & 145 & 5 & 8 & 7.19 & 1.086 \\
\hline 16 & OP52 & 145 & 5 & 8 & 5.92 & 0.965 \\
\hline 17 & OP53 & 145 & 5 & 8 & 6.70 & 1.138 \\
\hline 18 & OP54 & 145 & 5 & 8 & 5.46 & 0.677 \\
\hline 19 & OP61 & 145 & 5 & 8 & 5.89 & 1.100 \\
\hline 20 & OP62 & 145 & 5 & 8 & 5.87 & 1.156 \\
\hline 21 & OP63 & 145 & 5 & 8 & 6.66 & 1.320 \\
\hline 22 & OP64 & 145 & 5 & 8 & 6.61 & 0.900 \\
\hline 23 & OP71 & 145 & 5 & 8 & 5.92 & 1.149 \\
\hline 24 & OP72 & 145 & 5 & 8 & 5.80 & 0.813 \\
\hline 25 & OP73 & 145 & 5 & 7 & 5.73 & 0.690 \\
\hline 26 & OP74 & 145 & 5 & 8 & 5.54 & 1.155 \\
\hline 27 & OS & 145 & 5 & 7 & 6.13 & 0.490 \\
\hline
\end{tabular}

In order to predict the freight owners' satisfaction (OS) on RT services, the multiply regression analysis was adopted. In the 
analysis, OP1, OP2, OP3, OP4, OP5, OP6 and OP7 are independent variables; the passengers' satisfaction (OS) is dependent variable. The multiply regression equation can be written as:

$$
O S=\beta_{O 0}+\beta_{O 1} . O P 1+\beta_{O 2 .} . O P 2+\beta_{O 3 .} . O P 3+\beta_{O 4 .} . O P 4+\beta_{O 5 .} . O P 5+\beta_{O 6} . O P 6+\beta_{O 7 .} . O P 7
$$

where, $\beta_{O i}(\mathrm{i}=1 \ldots 7)$ are beta coefficients - one to go with each independent variable. In the equation, because the constant (beta zero) is included, these coefficients are unstandardized. In this study, the data were analyzed using SPSS version 20.0. The results of analysis are presented in Table 10.

Table 10

Multiple regression results of the analysis on freight owners' satisfaction

\begin{tabular}{lcccc}
\hline \multirow{2}{*}{ Variable } & \multicolumn{2}{c}{ Unstandardized Coefficients } & Standardized Coefficients & \multirow{2}{*}{ Sig. } \\
\cline { 2 - 4 } (Constant) & $\beta_{\mathrm{i}}$ & Std. Error & Beta & 0.720 \\
OP1 & $\mathrm{B}_{\mathrm{O} 0}=0.197$ & 0.274 & 0.198 & 3.594 \\
OP2 & $\mathrm{B}_{\mathrm{O} 1}=0.147$ & 0.041 & 0.223 & 0.473 \\
OP3 & $\mathrm{B}_{\mathrm{O} 2}=0.168$ & 0.037 & 0.168 & 3.505 \\
OP4 & $\mathrm{B}_{\mathrm{O} 3}=0.116$ & 0.031 & 0.116 & 3.699 \\
OP5 & $\mathrm{B}_{\mathrm{O} 4}=0.088$ & 0.040 & 0.188 & 2.192 \\
OP6 & $\mathrm{B}_{\mathrm{O} 5}=0.140$ & 0.037 & 0.191 & 3.772 \\
OP7 & $\mathrm{B}_{\mathrm{O} 6}=0.147$ & 0.039 & 0.153 & 3.811 \\
\hline
\end{tabular}

Table 11

Results of ANOVA test for the freight owners' satisfaction model

\begin{tabular}{|c|c|c|c|c|c|}
\hline Model & Sum of Squares & $\mathrm{df}$ & Mean Square & $\mathrm{F}$ & Sig. \\
\hline Regression & 48.299 & 7 & 6.900 & 70.197 & $0.000^{\mathrm{t}}$ \\
\hline Residual & 13.564 & 138 & 0.098 & & \\
\hline Total & 61.864 & 145 & & & \\
\hline \multicolumn{6}{|c|}{$\mathrm{R}^{2}$ test } \\
\hline Model & $\mathrm{R}$ & $\mathrm{R}^{2}$ & Adjusted $\mathrm{R}^{2}$ & \multicolumn{2}{|c|}{ Std. Error of the Estimate } \\
\hline 1 & $0.884^{\mathrm{a}}$ & 0.781 & 0.770 & \multicolumn{2}{|c|}{0.314} \\
\hline
\end{tabular}

With Sig $<5 \%$, all regression coefficients $\beta_{O i}(\mathrm{i}=0-7)$ are statistically significant. F value of 70.197 and $\mathrm{Sig} .=0,000<5 \%$ (ANOVA test); $\mathrm{R}^{2}=0.781\left(\mathrm{R}^{2}\right.$ test) show that the model is a good fit for the data and $52.2 \%$ of the variance was accounted for. The regression equation is as follows,

$$
O S=0.197+0.147 . O P 1+0.168 . O P 2+0.166 . O P 3+0.08 . O P 4+0.140 . O P 5+0.147 . O P 6+0.134 . O P 7 .
$$

Based on the above regression equation, Price (OP2) and Place (OP3) have the largest impact on freight owners' satisfaction.

\section{Discussions and implications}

The study findings have revealed the relationship between the main independent variables (the marketing mix elements: price, place, promotion, people, physical evidence, and process) and the dependent variable (the consumers' satisfaction on RT services). Of the independent variables, price element has the largest effect on customer satisfaction on RT services. In order to increase the satisfaction level of customers, several suggestions are as follows:

- RT company must adjust the method to calculate rail transport fares and costs in compliance with the current new situation. The transport costs consist of two main parts: the first part is allocated for the railway infrastructure fee and the rest is the cost at the RT company. Of the above 2 cost portions, RT company can only adjust the first part. The RT company must spend expenses items reasonably, efficiently and economically to reach the target of cost reduction and lower price.

- RT Enterprises need to complete the new online channel by diversifying and enriching sales channels, meeting the tastes of train passengers through applying scientific technologies in the process of buying tickets, helping passengers to access in the easiest way. With the limited budget for marketing activities, using E-marketing is an effective solution. In order for Emarketing to reach its targets, RT Enterprises need to integrate the above tools to achieve the highest possible performance. E-marketing tools may include: website marketing, email marketing, search engine optimization (SEO).

- RT company should improve the service quality of staffs who work directly with passengers. There are two main groups including the on-board staffs and at-the-station staffs. Several solutions are: regular training and upgrading of professional qualifications; improve the communication skills of service personnel (both on-board and at-the-station staffs); implement an appropriate remuneration package for on-board and at-the-station staffs.

- RT company must establish a standard service processes including service process for passengers boarding a train at the station; service process for on-board passengers; and service process for passengers detraining at the destination station. 
- Stations and station architecture should be improved. At large stations, there are a large number of often tourists, it is advisable to arrange a waiting room specifically intended for this type of passengers. Reconstruct the radio system on board and at the station, adjust the sound system properly so that passengers can hear the broadcasted information clearly. Create mobile storages to solve the problems related to the unloading of cement, phosphate.

- It is necessary to develop means of transportation: renovation, upgrading and replacement of old locomotives; assembling, manufacturing new locomotives; renovating and upgrading old railway carriages; Import, build new high-quality railway carriages.

Moreover, RT Enterprises transport a variety of goods from chemicals, rebar of all kinds, construction materials (diatomite brick), home appliances to agricultural products. So, the preservation to maintain the good quality services in transportation of commodities during the transportation is especially important. If this cannot be guaranteed, goods cannot be consumed in the market. At the end of the transportation process, the consignee will inspect the seals, the goods' quality, then accept and receive the goods. The goods are transported by RT Enterprises through many stages, processes, procedures from departure place to destination. Goods are transported to the station, which is then loaded onto the wagons, after reaching the destination station, goods are unloaded at stations and the transport process is finished when the goods are delivered to the consignee. Avoiding the loss or damage of transported goods can be managed upon the stages of the transport process: Goods are loaded onto the wagons, Goods are on the way of transferring, and Goods are unloaded at destination stations. During the above stages of freight transport, RT Enterprises shall be responsible for the whole process from when the goods are sealed, leaded, invoiced until the goods are handed over to the owners/consignees.

During the freight transport of RT Enterprises, depending on the type of transported goods, escort personnel are required and they are in charge of technique and freight safety issues: goods caring and fire prevention. In order to ensure safety when participating in the freight transport process, the escort personnel must firmly grasp the process, technique and characteristics of the goods to be transported; strictly follow the regulations to make sure of the safety of goods. In addition to ensure the safety of railway personnel participating in the freight transport, the safety of traffic participants is also important. Currently, Vietnam Railways regularly encounters incidents and obstacles that affect the smooth flow of the entire route during freight transport and passenger transport. These issues can be divided into two groups: objective incidents and subjective incidents. Objective incidents are often accidental incidents caused by crashing, striking with people and vehicles outside the railway sector due to violations of architectural contiguity and violations of regulations on crossroads. Subject incidents are RT Enterprises' own obstructive problems: carriage failure, locomotive failure, freight contract issues, and service process violations. The characteristics of freight transport process is not to use labor tools to change the physical appearance and physical \& chemical properties of the labor objects.

\section{Conclusions}

RT Enterprises are facing to the sharp decline in the number of passengers and freight transport volume, the study has investigated the relationship between the marketing mix components and consumers' satisfaction and given several suggestions to maximize the satisfaction for the demand of passengers and freight owners. The study proposed two satisfaction model based on multiple regression method for passengers and freight owners. With the application of the proposed method for measuring the consumers' satisfaction on RT services it comes to increased objectivity by using the subjective opinions of customers, freight owners, and by using this method and testing its results and statistical software for the consistency coefficient, we may obtain some insight about the target group about the quality of the services. Also based on the research results, RT Enterprises can measure the impact of each group of factors affecting the satisfaction of the RT service users in certain periods. The

solutions proposed in the study may satisfy the current existing customers and incite customers using other means of transportation to switch to RT services and also attract new customers.

\section{References}

Agu, A. G., Ikenna, M. H., \& Ben, U. D. (2017). Determinants of passenger preference for long distance shuttle services in Nigeria.

Agu, G. A., \& Ogbuji, C. N. (2008). A survey of factors influencing patronage of road transport firms. Journal of Business Financ, 2(1).

Beck, A. (2011). Barriers to entry in rail passenger services: empirical evidence for tendering procedures in Germany. European Journal of Transport and Infrastructure Research, 11(1).

Booms, B. H., \& Bitner, M. J. (1982). Marketing services by managing the environment. Cornell Hotel and Restaurant Administration Quarterly, 23(1), 35-40.

Duncan, T. (2005). Principles of Advertising \& IMC, 2nd edn. Taylor \& Francis.

Ivy, J. (2008). A new higher education marketing mix: the 7Ps for MBA marketing. International Journal of educational management, 22(4), 288-299.

Jin, B., \& Gu Suh, Y. (2005). Integrating effect of consumer perception factors in predicting private brand purchase in a Korean discount store context. Journal of Consumer Marketing, 22(2), 62-71.

Kim, J. H., \& Hyun, Y. J. (2011). A model to investigate the influence of marketing-mix efforts and corporate image on brand equity in the IT software sector. Industrial Marketing Management, 40(3), 424-438. 
Laisi, M. (2010). Business environment and future opportunities in Russian railway freight market.

Mostaghel, R. (2006). Customer satisfaction: service quality in online purchasing in Iran. http://www.diva-portal.org/smash/record.jsf?pid=diva2\%3A1025401\&dswid=-2938

Mullins, J., Walker, O. C., \& Boyd Jr, H. W. (2012). Marketing management: A strategic decision-making approach. McGraw-Hill Higher Education.

Nunnally, J.C.; Bernstein, I. H. (1994). The assessment of reliability. In Psychometric Theory. https://doi.org/10.1037/018882

Rafiq, M., \& Ahmed, P. K. (1995). Using the 7Ps as a generic marketing mix: an exploratory survey of UK and European marketing academics. Marketing Intelligence \& Planning, 13(9), 4-15.

Tolba, A. H. (2011). The impact of distribution intensity on brand preference and brand loyalty. International Journal of Marketing Studies, 3(3), 56.

Vargo, S. L., \& Lusch, R. F. (2014). Evolving to a new dominant logic for marketing. In The Service-Dominant Logic of Marketing (pp. 21-46). Routledge.

Wood, L. M., \& Pierson, B. J. (2006). The brand description of Sainsbury's and Aldi: price and quality positioning. International Journal of Retail \& Distribution Management, 34(12), 904-917.

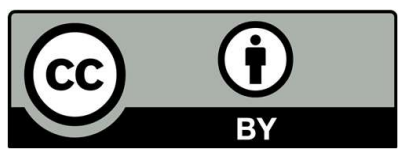

(C) 2020 by the authors; licensee Growing Science, Canada. This is an open access article distributed under the terms and conditions of the Creative Commons Attribution (CC-BY) license (http://creativecommons.org/licenses/by/4.0/). 